\title{
National Information Policies - A Comparative Study with Particular Reference to South Africa and School Libraries
}

\author{
Anna-Marie Arnold \\ CSIR, \\ P.O. Box 395 , \\ Pretoria, \\ South Africa \\ amarnoldaiafricacom. AArnold@csir.ac.za
}

\begin{abstract}
The government of South Africa has committed itself towards the obliteration of poverty and to achieve social and economic development. National information policies are used by countries to address these and other problems. A national policy is generally motivated by public and political party concerns and legislation is passed as the best option to meet the ideal set by the government for the issue(s) on hand. Within modern society education can be linked to national development. School libraries form an integral part of the modern approach to teaching and learning. School library development in South Africa is shown to be problematic in a number of ways. Similar problems exist in other African countries. Recommendations are made for the government of South Africa to address these issues in a national information policy. Many other African countries should also address the development of school libraries.
\end{abstract}

\section{Introduction}

The main area of my research over the past five years has been on national information policy with particular reference to South Africa. Part of my paper today is based on some of the findings of my original research. In addition to this I have added further research findings on the subject of this paper as well as some personal observations within the profession based on the time that I worked as teacher-librarian at a school in Pretoria, South Africa. In this paper I describe the situation of school libraries in South Africa and investigate how problems in this field could be addressed within a national information policy.

By way of introduction I explain the role of national policies and how these policies reveal what value governments attach to the issues they choose to address in their national policies. National information policy is explained as a particularly complex type of national policy, due to its many facets. South Africa.

The main body of the paper is concerned with the situation of school libraries in 


\section{National policies and the values they reflect}

A national policy is generally motivated by public and political party concerns rather than by social, economic or cultural issues, such as education and employment (Sabatier, 1995, p.10).

A national policy is also developed within the political environment as part of governmental activity and is the result of a rational political process. The focus of this process is the interest of the public (Parsons, 1995, p.7). The outcome of such a process of policy formulation may be expressed in any or all of the following:

(i) the clarifying of public values and intentions;

(ii) the commitment of money and services;

(iii) the granting of rights and entitlements (Considine, 1994, p.3,4).

Public policy expressed in any or all of the above three formulations reflects a number of things, such as:

"... what governments should do and what they actually do; what governments actively do and do not do; involves all levels of government; formal and informal actors; public policy is not only limited to legislation, executive orders, rules and regulations; has an intended course of action and goal; both short-term and long-term; it is an ongoing process; it involves decisions to enact law and implementation, enforcement and evaluation; it involves politics and environment." (Theodoulou \& Cahn, 1995, p.49)

Governments respond to the needs of their citizens by passing legislation about areas which fall within their jurisdiction. Legislation is therefore passed whenever it is considered the best option to meet the ideal set by the government for the issue(s) on hand. This legislation can thus be seen as a reflection of the value attached to the issue(s).

Many national policy documents emphasize the link between social and economic development (Hagg, 2000, p.49). The government in South Africa has committed itself towards the obliteration of poverty and to achieve social and economic development (Dilotsothlhe, 2000).

\section{Education and National Development}

Within modern society, education can be linked to national development. Education is necessary for the development of skills, which enable the educated to participate and be employed within the economic sector.

The aim of education is to

"... develop a rational, responsible and responsive person; a person who is welladjusted, can lead a satisfying professional and private life, and participate in society" (Fairer-Wessels, 1990, p.290).

An educated person will generally be literate and able to use information for daily decision-making and problem-solving (Fairer-Wessels, 1990). The achievement of a good education and well-developed levels of information literacy can be facilitated and supported by school libraries. Information literacy can be defined in its broadest sense as

"... a person's ability to access and understand a variety of information resources." 
Information literacy is an essential intellectual skill required by the modern world. The issue of information literacy is identified by Bundy not as a library issue, but as an educational and societal issue (Tise, 2000, p.59).

\section{School libraries and education}

School libraries form an integral part of the modern approach to teaching and learning where the emphasis lies on independent, media-based learning and where textbooks are of lesser importance.

This is also the approach of the new curriculum which is currently being phased into South African schools. However, school library development in the country does not reflect this approach.

\section{School libraries and education in South Africa}

School library development in South Africa has been problematic since its inception (Witbooi, 1997). The development of school libraries in South Africa must be understood within the country's history and developments under its previous government and its policy of segregation of its different population groups from 1948 to 1994. Different departments of education controlled formal education in primary and secondary education. This policy resulted in a very skewed education system. Each of the departments of education supported only the media centers within its department, with the result that school libraries and media centers developed in an uncoordinated manner. (Olën, 1988, p.213).

School libraries were introduced in schools in South Africa in about 1950. However school libraries continued to develop unequally despite calls for the cooperation between the various education services. the following:

A brief review of current conditions regarding school libraries in South Africa reveals

(i) A recent nation-wide survey indicated that eight million out of the 12 million scholars in South Africa do not have access to library facilities at a time when the new resource-based education is being introduced by the Department of Education.

(ii) Although the Department of Education has been restructured into one department since 1994, limited organization continues to characterize the provision for school libraries and facilities.

(iii) Library facilities and accommodation are limited and in many instances school libraries are housed in very small areas.

(iv) The number of full-time school librarians is limited, with most full-time school librarians having to teach other subjects and manage the school library as well.

(v) In many of the school libraries the library collection is fairly limited due to restricted budgets.

(vi) There are no school library standards with regard to the minimum standards of the book collection, budget and information requirements that must be addressed (Vermeulen, 1997).

(vii) The school libraries are often managed by teachers who are not trained librarians.

(viii) Libraries are often poorly funded and considered of less importance than computer centres to which are more likely to be allocated. 
(ix) The South African government has committed itself to strive to provide e-mail access to every scholar, while failing to set minimum standards for the provision of basic school library facilities to meet the information needs of scholars and teachers.

Vermeulen (1997: 36) describes the situation in South African departments of education as follows:

"... South African departments of education seem to have been paying mainly lip service to modern educational principles. School libraries which are regarded as an essential and integral part of the independent learning process on which modern education hinges, are either completely lacking in schools, under-achieving, or in decline".

Vermeulen explains that the main reason why the above situation is faced in South African is due to the lack of any official guidelines regarding school libraries.

\section{Government Policies towards School Libraries in Africa}

The poor state of school libraries can also be observed in other countries in Africa. School library facilities in other southern African countries are described by Rosenberg in 1999. She found school libraries to be the worst off of all the libraries in many African countries, such as Zambia and Namibia (Rosenberg, 1999). She paints a grim picture of the current state of school libraries in Africa as having been positioned last in the order of priorities. In most instances school libraries in the region either do not exist or are no more than a few outdated books in run-down buildings.

In South Africa and the other African countries where school libraries are in decline, struggling to survive, or non-existent, one may blame the governments for failing to consider access to information as a basic requirement within their education systems.

\section{National information policies and school libraries}

Access to information and the ability to use information are areas where school libraries can make a huge contribution during the formative years of scholars in preparation for an information society. A Working Party on School Library Services in the United Kingdom explained the value of a school library to a nation as follows:

"... We believe that the nation will pay a heavy penalty for many years to come if it continues to neglect the self-evident contribution which school libraries could make in producing citizens who are self-reliant, well adjusted, and above all, able to make use of information." (Olën, 1988, p.232)

The warning expressed in the above quotation indicates that the deficiencies observed in school libraries in South Africa and some of the neighboring countries in the region need to be addressed.

In the process of addressing the deficiencies observed in school libraries in a country like South Africa two questions may be asked:

(i) How can school libraries be used to address education-related problems in South Africa?

(ii) How are problems similar to those in South Africa addressed in other countries? 
These questions are addressed below in order to find ways and means to address the deficiencies in school libraries in South Africa.

\section{Education and school libraries in South Africa}

South Africa is a developing country and has a number of education-related problems. These problems are relevant to this paper as these problems need to be addressed together with the need to meet some basic requirements in the provision of school libraries. I will list the problems and then cover each briefly before moving on to illustrate how similar problems are addressed in other countries in their national policies.

Some of the education-related problems in South Africa are the following:

(i) the high rate of illiteracy;

(ii) discrepancies in the level of education and the lack of skills in the population at large;

(iii) the information content in South Africa and the North-South divide;

(iv) developments towards an information society are problematic;

(v) the lack of computer literacy and information technology in a country with great poverty;

(vi) limited access to telecommunication and the high cost of connectivity due to the monopoly of in the industry in South Africa;

(vii) copyright issues and a general reluctance to generate own material. paragraphs.

These seven education-related problems are explained briefly in the following

\section{High rate of illiteracy}

Approximately 45 per cent of South African adults are illiterate (Macfarlane, 2000). Macfarlane explains that many areas of society are affected by illiteracy, such as:

"... HIV/AIDS awareness, small business development, environmental education, tourism training, parent/child relationships, primary health care, interventions, land resettlements, work-place productivity levels, human rights and democracy education"

(Macfarlane, 2000, p.18)

These issues are all problem areas in South Africa and they could be addressed in a more effective way by a society which is literate. One such area where government action could be far more proactive in addressing problems would be for instance the distribution of written notices to address health issues in areas where rivers are infected by an outbreak of cholera, or in fighting the spread of HIV/AIDS.

School libraries can play an important role in literacy training for scholars by ensuring that the facilities and guidance are in place for scholars to achieve higher literacy levels. High levels of literacy cannot be achieved without guidance and the necessary resources. Certain standards should be set for the provision of information and reading resources in school libraries, each of which should ideally be manned by a librarian who is trained and skilled to facilitate the use of the library material.

Literacy involves the following:

"... the integration of listening, speaking, reading, writing and critical thinking; it incorporates numeracy. It includes the cultural knowledge which enables a speaker, 
writer or reader to recognize and use language appropriate to different social situations. For an advanced technological society... the goal is to achieve literacy which allows people to use language to enhance their capacity to think, create and question, in order to participate effectively in society." (Campbell, 1994, p.315).

School libraries could also be used to support evening schools which offer adult literacy classes. Basic literacy training in South Africa requires encouragement and active involvement by all levels of government. A national conference convened by the NGO Project Literacy and the European Union in 1999 established that very little money is allocated to adult education by the South African government. It was stated at the conference that only 0,8 per cent of the education budget of R47,8 billion in 1999/2000 was spent on non-formal education. Most of the 0,8 per cent was spent on young people who failed matric and were attempting the matriculation examination for a second time. The lack of government funding was not helping the country to address the problem of illiteracy. Illiteracy is affecting the economy of the country negatively and should be given priority, just as school libraries should be more valued for their place in education.

\section{Discrepancies in the level of education and the lack of skills in the population at large}

The majority of the South African population is poorly educated while a relatively small number of people are well educated. As a result of the generally poor levels of education the majority of the South African workforce is found lacking in skills, with only one in five adults being skilled for the labour market. In this area the school library could once again be used to address the basic educational needs of scholars and adult learners.

\section{The information content in South Africa and the North-South divide}

The bulk of South Africa's information is not generated from within the country by the population itself, but originates in the developed countries of the northern hemisphere as most research is conducted and published in these northern countries. The imbalance of information production results in a dependence on information sourced from the developed countries of the northern hemisphere. This phenomenon is often referred to as the NorthSouth divide.

The result of this trend is an undue dependence on foreign information sources. This form of information dependence impacts negatively on the number of books and research articles published annually in South Africa (and similarly in other countries in sub-Saharan Africa) in comparison with the rest of the world. In 1991 sub-Saharan Africa produced only 12 per cent of the world's book titles. The lack of a strong indigenous information handling capacity in South Africa and the dominance of the North-South flow of information, and the inadequate production of information in the South caused Africa to be described at the end of the 1980 s as a "bookless society" with schools not having books, research being crippled, and African academics being increasingly marginalised.

These conditions impact negatively on education in South Africa and the flow of information, perpetuating a dependence on the countries in the developed world (Lor, 1996, p.1-3). School libraries can, however, foster a love of learning, reading and language skills. Information skills can be nurtured and developed under the guidance of an equipped librarian. Teachers and scholars can benefit from the access to information within the school environment in their school library. 


\section{Developments towards an information society appear to be problematic}

Both literacy and information literacy are necessary skills required by individuals in order to benefit from the information age (Behrens, 1994, p.312). These skills are also essential in the process of lifelong learning and are beneficial skills, equipping individuals to continue to learn and develop their abilities or skills. In this area the school library can play an invaluable role in the education and training of scholars and other learners.

The ability to learn needs to be fostered in South Africa in order for the country to achieve a better educated and trained workforce, and promote innovative developments and growth in the job market and economy. These developments may help reduce the high level of unemployment.

\section{Computer literacy and information technology in a country with great poverty}

Nearly half the population of South Africa lives in extreme poverty and in desperate social conditions. Current government policy for the country's development towards the global economy is to prioritize investment in the information and communication technology sector in order to "bridge the digital divide". This strategy is taken in support of the Millennium Africa Renaissance Program, which was launched in 2001 at the World Economic Forum in Davos (Laing, 2001, p.14). Economic development and growth to bridge the divide between the poor and rich nations forms the aim of the African Renaissance Program in the participating countries on the African continent. However, the levels of poverty may limit the application of information technology to access information electronically via the Internet, online databases, CD-Rom or other sources.

At the education and school levels the government should reconsider spending large amounts of money on information technology in preference to the developing of school libraries. In this regard the emphasis should not be on the ability to download information which is accessed electronically. Emphasis should be on the ability to assess, evaluate and use information for problem-solving or other applications.

Once again the potential value of school libraries within education in South Africa and else where in Africa becomes evident.

\section{Telecommunication and high cost of connectivity}

The current cost of telephone calls in South Africa is relatively high (currently at R0,60 per 3 minutes call). This results in a high cost of Internet connectivity for users of this form of information communication. Despite this, the government favours e-mail connectivity for scholars. This type of connectivity is more likely to be provided within the application of computer studies in computer centres than in the school library. Such connectivity also pre-supposes a reasonable level of literacy. Furthermore, the high cost of Internet connectivity makes it less affordable for school libraries to be given access to electronic-based media resources.

\section{Copyright and the unwillingness to generate original material}

Copyright protects the intellectual property of the owner or the creator of original work. Intellectual property is of major importance to the economic growth of a country in the current knowledge based society where "... the keys to job creation and higher standards of living are innovative ideas and the application of technology in services and manufacturing." (The hot desktop debate, 1999, p.37, 38). The importance of intellectual property protection is stressed by Bauer. She points out that intellectual property protection is "... critical to a 
country's ability to attract investment". Ignorance or a lack of appreciation of copyright protection is cause for concern in South Africa. This can be illustrated by the losses in trade with the United States of America in 1998 which amounted to R853 million.

Adherence to the requirements set out in the copyright law could be taught within the education system in South Africa to inform teachers and scholars. The school library can play an important role in creating an awareness and understanding of copyright protection, especially in the light of the fact that photocopying is often done in the school library.

The above seven education-related problems are also to a large extent informationrelated problems. These educational and information-related problems are addressed in other countries by their governments by means of national information policies. The next section explains the findings of a comparative analysis of the national information policies in a number of countries and summarizes the findings of the survey by listing the type of issues addressed in the national information policies in the countries that were included in the comparison.

\section{National policies used in other countries to address problems similar to those in South Africa}

A survey was conducted on national information policies in countries in the West, East, Latin America and Africa. The following elements of the policies were identified:

- $\quad$ Policy goals (intentions behind the policy);

- Policy content (manifestations of the policy);

- Policy instruments (institutions who regulate the policy);

- $\quad$ Policy outcomes (positive or negative consequences of implementation);

- $\quad$ Policy styles (processes through which policies are formulated) (Dye, 1995, p.2).

A comparison of this nature is often crude, but can give valuable results. The comparison of the type of issues addressed in the national information policies in the countries included in the study are summarized in Table 1 on the following page. The table lists the issues that are addressed and gives an example of a country where the issue is addressed in its national information policy. The list reflects a trend to address the national information-related issues in a national information policy. This type of policy is introduced by governments is all parts of the world as a measure to address generally more than one issue which is considered of importance by that government. A policy is an expression of the value attached to a particular issue in a country.

School libraries are not specifically addressed in the national information policies of the countries included in this study. However, other related and more broader issues are addressed in national information policies. Broader issues include libraries, access to information, literacy, and the development of an information society. A trend can therefore be observed that governments address issues such as those identified in this paper in national information policies. 


\section{Table 1}

List of issues typically addressed in national information policies in various countries and examples of applicable countries.

\begin{tabular}{|c|c|c|}
\hline Symbol & $\begin{array}{l}\text { Issue addressed in National } \\
\text { Information Policy (NIP) }\end{array}$ & $\begin{array}{l}\text { Example of county where the issue } \\
\text { is addressed in NIP }\end{array}$ \\
\hline A & $\begin{array}{l}\text { North-South divide / information } \\
\text { dependence / impact on economy }\end{array}$ & $\begin{array}{l}\text { Algeria; Canada; China; Egypt; } \\
\text { France; France; Germany; } \\
\text { Netherlands; Papua New Guinea; } \\
\text { Portugal; Sweden; Thailand; } \\
\text { Zambia; }\end{array}$ \\
\hline B & $\begin{array}{l}\text { Information content, industrial } \\
\text { competitiveness \& innovation }\end{array}$ & $\begin{array}{l}\text { USA; Australia; Austria; China; } \\
\text { Indonesia; Japan; Netherlands; } \\
\text { Portugal; Spain; Sweden; Thailand; } \\
\text { United Kingdom; }\end{array}$ \\
\hline $\mathrm{C}$ & Literacy & $\begin{array}{l}\text { Algeria; China; Columbia; New } \\
\text { Zealand; Papua New Guinea; } \\
\text { Thailand; United Kingdom; }\end{array}$ \\
\hline $\mathrm{D}$ & Computer literacy & Egypt; France \\
\hline E & Education / skills training & \\
\hline $\mathrm{F}$ & Information society development & $\begin{array}{l}\text { China; Denmark; France; Namibia; } \\
\text { Netherlands; Senegal; Sweden; } \\
\text { Thailand; United Kingdom; }\end{array}$ \\
\hline G & Telecommunication issues & $\begin{array}{l}\text { Denmark; Egypt; Ethiopia; France; } \\
\text { Mozambique; Netherlands; Portugal; } \\
\text { Senegal; Sweden; Uganda; United } \\
\text { Kingdom; }\end{array}$ \\
\hline $\mathrm{H}$ & Copyright & Chile; Mexico; Portugal; USA \\
\hline I & Industrial property rights & Canada; \\
\hline $\mathrm{J}$ & Government communication & Algeria; Canada; Egypt; USA; \\
\hline $\mathrm{K}$ & Access to information & $\begin{array}{l}\text { Australia; Canada; China; Germany; } \\
\text { Columbia; India; Indonesia; Japan; } \\
\text { Malaysia; Mexico; Namibia; } \\
\text { Netherlands; Nigeria; Portugal; } \\
\text { Sweden; Thailand; United Kingdom; } \\
\text { Zambia; USA }\end{array}$ \\
\hline $\mathrm{L}$ & Censorship & Nigeria; USA \\
\hline $\mathrm{M}$ & Information ownership & Canada; Chile; USA \\
\hline $\mathrm{N}$ & Freedom of speech & Canada; Ghana; Namibia; USA \\
\hline $\mathrm{O}$ & Privacy & \\
\hline $\mathrm{P}$ & Intellectual freedom & United Kingdom \\
\hline Q & $\begin{array}{l}\text { Other (such as libraries, reading, } \\
\text { books, culture, }\end{array}$ & $\begin{array}{l}\text { Argentina; Australia; Columbia; } \\
\text { Denmark; Germany; Indonesia; } \\
\text { Mexico; Peru; Portugal; Senegal; } \\
\text { United Kingdom; Zambia }\end{array}$ \\
\hline
\end{tabular}

\section{National information policy and school libraries in South Africa}

School libraries are generally accepted to form an integral part of the modern approach to teaching and learning. However, school libraries are either inadequate, in decline, or totally lacking in South African schools. The government has no basic standards or procedures for this type of library in South Africa nor has the Department of Education. 
Other problems are also observed within education in South Africa. Examples of these problems concern

- $\quad$ the North-South divide and the problem of information dependency;

- the different levels of education and the lack of skills in South Africa;

- the information content in South Africa;

- the difficulties concerning the development of an information society;

- $\quad$ problems concerning computer literacy in South Africa;

- $\quad$ copyright and intellectual property need to be respected.

These education problems are all information-related problems. A summary of a comparative analysis of the main issues addressed in national information policies in other countries is used to illustrate a trend concerning this type of policy. It shows that similar information-elated problems are addressed in the national information policies in other countries.

\section{Conclusion}

In conclusion it is therefore recommended that the South African government address the information-related problems discussed in this paper and also introduces a formalized policy regarding the development of school libraries in South Africa.

If the government is truly committed to its expressed policy that it wishes to develop an information society in the country, its policies should reflect similar values. The government of South Africa should observe world trends with regard to national information policies and pay attention to the country's national information-related problems which should be addressed. One such problem is the need for a school library in each school in the country. As long as the South Africa government fails to address this issue, it will be failing to ensure the successful provision of sound education facilities in the country's education system.

The ideal scenario is for each school in Africa to have a school library. If the governments in all the African countries would make this part of their national policies they would indeed be laying the corner stone of the African Renaissance. It is imperative for the whole of Africa to become an information society in anticipation of the emerging knowledge society.

\section{References}

Behrens, S.J. (1994) A conceptual analysis and historical overview of information literacy. College and Research Libraries, July, 309-322.

Campbell, B. In: Behrens, S.J. (1994) A conceptual analysis and historical overview of information literacy. College and Research Libraries, July, 315.

Considine, M. (1994) Public policy: a critical approach. South Melbourne: Macmillan Educational Australia. 
Dilotsothlhe, K. (2000) The role of the Directorate of Science and Society of the Department of Arts, Culture, Science and Technology in promoting science and technology information and socio-economic development. Meta-info Bulletin. 9(2): 32.

Dye, T. (1995) In S.Z. Theodoulou \& M.A. Cahn (Eds.), Public policy: the essential readings. Englewood Cliffs: Prentice Hall.

Fairer-Wessels, F.A. (1990) Community information in the school media centre. South African Journal of Library and Information Science, 58(3): 290.

Hagg, G. (2000) What is socio-economic development and what are the aims? Meta-info Bulletin, 9(2): 5-25.

Laing, R. (2001) Entrepreneurship: the missing road in Mbeki's map. Pretoria News: IT Technology, 13 February: 14.

Lor, P.J. (1996) Information dependence in Southern Africa: global and subregional perspectives. African Journal of Libraries, Archives and Information Science, 6(1): 19.

Macfarlane, D. (2000) Almost half of SA is illiterate. Mail \& Guardian, 1-7 December: 18.

Olën, S. (1988) The media centre in the school. In N. Shillinglaw \& N. Thomas, N. (Eds.), The Information Society. Craighall: Donker.

Parsons, W. (1995) Public policy: an introduction to the theory and practice of policy analysis. Cambridge: University Press.

Rosenberg, D. (1999) The sustainability of libraries and resource centres in Africa. In C. Stilwell, A. Leach \& S. Burton (Eds.), Knowledge, information and development: an African perspective. Pietermaritzburg: University of Natal: 12-27.

Sabatier, P.A. (1995) Political science and public policy. In S.Z. Theodoulou \& M.A. Cahn (Eds.), Public policy: the essential readings. Englewood Cliffs: Prentice Hall.

Theodoulou, S.Z. \& Cahn M.A. (Eds.) (1995) Public policy: the essential readings. Englewood Cliffs: Prentice Hall.

Tise, E. (2000) The role of libraries in socio-economic development and the need for information literacy. Meta-info Bulletin, 9(2): 59.

The hot desktop debate. (1999) Financial Mail, 17 December: 37,38.

Vermeulen, M.W. (1997) School libraries. Meta-info Bulletin: 34-36.

Witbooi, S. (1997) Overview of the current state of LIS in South Africa. Meta-info Bulletin: 32. 